\title{
KONSEP PENDIDKAN ANAK MARGINAL DALAM PERSPEKTIF PENDIDIKAN BERBASIS MASYARAKAT
}

\author{
Meri Sandora \\ Universitas Islam Negeri Sultan Syarif Kasim Riau, Indonesia \\ meri.sandora@gmail.com
}

\begin{abstract}
$A B S T R A C T$
This study aims to determine how education for marginalized children. The methode used in this research is literature study. The results showed that there are still marginal children in our society. Marginal children have not received their rights as children in general, especially in terms of getting education both formal and informal. This is motivated by the family's economy, and social conditions. In this study it can be concluded that marginal children have not received a proper education, whereas currently there is a shelter for them to get education and skills. But unfortunately this halfway house has not been well socialized to them. This shelter is as a place for them to get education and skills so that they have the expertise to obtain a more decent job.
\end{abstract}

Keywords: Education of Society-Based; Marginal Children; Shelter

\begin{abstract}
ABSTRAK
Penelitian ini bertujuan untuk mengetahui bagaimanakah pendidikan untuk anak-anak yang termarginalkan. Metode yang digunakan dalam penelitian ini adalah studi kepustakaan. Hasil penelitian menunjukkan bahwa masih terdapatnya anak marginal pada masyarakat kita. Anakanak marginal ini belumlah mendapatkan hak-haknya sebagaimana anak-anak pada umumnya, terutama dalam hal mendapatkan pendidikan baik itu formal maupun informal. Hal ini dilatarbelakangi oleh ekonomi keluarga, dan kondisi sosial. Pada penelitian ini dapat disimpulkan bahwa anak-anak marginal belum mendapat pendidikan yang layak, padahal sekarang ini sudah terdapat rumah singgah untuk mereka mendapatkan pendidikan dan keterampilan. Namun sayangnya rumah singgah ini belumlah tersosialisasi dengan baik kepada mereka. Rumah singgah ini adalah sebagai tempat untuk mereka mendapatkan pendidikan dan keterampilan agar mereka mempunyai keahlian guna memperoleh pekerjaan yang lebih layak.
\end{abstract}

Kata Kunci: Anak Marginal; Pendidikan Berbasis Masyarakat; Rumah Singgah 


\section{PENDAHULUAN}

Istilah generasi penerus sebagai sebutan bagi anak-anak bangsa selalu menjadi substansi indah untuk konsumsi publik, baik dalam diskusi politik, ekonomi, sosial, budaya, termasuk pendidikan. Mereka adalah pemimpin masa depan, bahkan jika mereka orang yang bijak tidaklah berlebihan disebutkan dari sekarang bahwa diantaranya sebagai penabur benih kesejahteraan dan kebangkitan umat yang meneruskan cita-cita luhur perjuangan bangsa.

Dunia pendidikan menuntut anak bangsa untuk berperan mewujudkan cita-cita tersebut dan harus lebih dekat lagi dengan realitas kebutuhan masyarakat. Tidak itu saja pendidikan harus memberikan peluang yang sama bagi setiap manusia menapaki kehidupan. Tidak berlebihan kalau kita mengatakan semua pemikir muslim sepakat bahwa menuntut ilmu itu wajib bagi laki-laki dan perempuan, sebagaimana yang disabdakan oleh Nabi Muhammad s.a.w.. Apalagi ayat pertama yang diwahyukan kepada Rasulullah s.a.w. adalah perintah membaca/Iqro’ (Mujiburrahman, 2014).

Pada dasarnya manusia ingin memiliki rasa mampu (sense of power) dan rasa keteladanan (sense of models), akan tetapi keinginan tersebut terbentur oleh sekat-sekat keluarga, lingkungan dan keterbatasan akses lainnya yang menjadikan mereka sebagaimana manusia boneka. Kadangkala tradisi kehidupan sebagai pranata sosial yang telah disepakati selama ini menjadikan anak-anak negeri ini tetap dalam belenggu kebodohan.

Pendidikan adalah upaya mengembangkan potensi-potensi manusiawi peserta didik baik potensi fisik, potensi cipta, rasa, maupun karsanya, agar potensi itu menjadi nyata dan dapat berfungsi dalam perjalanan hidupnya. Dasar pendidikan adalah cita-cita kemanusiaan universal. Pengertian yang bersifat sederhana dan umum dikemukakan oleh M. Djumransjah yang memaknai pendidikan sebagai usaha manusia untuk menumbuhkan dan mengembangkan potensi-potensi pembawaan, baik jasmani maupun rohani, sesuai dengan nilai-nilai yang ada dalam masyarakat dan kebudayaan. M. Arifin mendefinisikan pendidikan sebagai suatu usaha untuk mengarahkan pertumbuhan dan perkembangan hidup manusia, sebagai makhluk pribadi dan sosial, kepada titik optimal kemampuannya untuk memperoleh kesejahteraan hidup di dunia dan kebahagiaan hidup di akhirat (HM. Djumransyah:2004).

Undang-undang Republik Indonesia No. 20 Tahun 2003 tentang Sistem Pendidikan Nasional menyatakankan bahwa, pendidikan adalah usaha sadar dan terencana untuk 
mewujudkan suasana belajar dan proses pembelajaran agar peserta didik secara aktif mengembangakan potensi dirinya untuk memiliki kekuatan spiritual keagamaan, pengendalian diri, kepribadian, kecerdasan, akhlak mulia, serta keterampilan yang diperlukan dirinya, masyarakat, bangsa dan Negara. (Sisdiknas, 2003). Selanjutnya dinyatakan bahwa fungsi pendidikan nasional adalah mengembangkan kemampuan dan membentuk watak serta peradaban bangsa yang bermartabat dalam rangka mencerdaskan kehidupan bangsa.

Disadari bahwa masa kecil, ketika dalam usia SD/SMP merupakan fase perkembangan yang paling subur, dan paling strategis untuk menggali potensi. Karena dengan kepolosan spiritual dan kelenturan jasmani, belum terkontaminasi dengan berbagai masalah sosial lainnya adalah pemberian bekal norma dan skills menjadi strategis. Akan tetapi ada sejumlah anak-anak sejak kecil telah dijadikan partner orang tua mencari nafkah. Bahkan kondisi ini menjadi lakonan hidup turun temurun. Anak-anak marginal ini, yang terpinggirkan dari perkembangan pesat ekonomi, keterbatasan akses informasi dan transportasi serta diselimuti persoalan sosial lainnya, telah membawa konsekuensi sejumlah anak di negeri ini tereliminasi dari hak-hak pendidikannya.

Tulisan ini akan mengungkapkan bagaimanakah pendidikan untuk anak-anak yang termarginalkan, dan diharapkan dapat memberikan masukan bagi masyarakat dan pemerintah untuk memperhatikan pendidikan bagi anak-anak marginal, supaya mereka memiliki masa depan untuk keberlangsungan hidupnya ke depan.

\section{METODE}

Metode yang digunakan dalam penelitian adalah metode penelitian deskriptif, yaitu metode yang membicarakan beberapa kemungkinan untuk memecahkan masalah aktual dengan jalan mengumpulkan data, menyusun atau mengklasifikasinya, menganalisis, dan menginterpretasikannya. Menurut Kutha dalam Gindarsyah (2010:30) menjelaskan, metode deskriptif analisis dilakukan dengan cara mendeskripsikan fakta-fakta yang kemudian disusul dengan analisis, tidak semata-mata menguraikan, melainkan juga memberikan pemahaman dan penjelasan secukupnya.

Obyek dalam penelitian ini adalah anak-anak marginal yang terdapat di jalanan. Adapun data yang diperoleh bersumber dari buku pelajaran, majalah, artikel baik dalam bentuk jurnal 
maupun internet, dan lain sebagainya. Data tersebut merupakan data sekunder. Teknik pengumpulan data menggunakan studi kepustakaan dan teknik wawancara.

\section{HASIL DAN PEMBAHASAN}

\section{Anak Marginal}

Dalam kamus bahasa Indonesia, marginal berarti kecil, tipis, tanah tepian dan atau pinggiran. Bila dikaitkan dengan kondisi masyarakat, berarti marginal adalah kelompok manusia yang masih dikategorikan terpinggir dari kemajuan zaman. Marginal (terpinggir atau pinggiran) adalah kategorisasi daerah/kelompok komunitas dan kondisi hidup dalam pranata sosial yang ditemukan tercecer dalam tatanan kehidupan masyarakat modern.

Variasi kondisi anak marginal dapat dilihat dari aneka ragam dan bentuk status ekonomi, lokasi geografis tempat tinggal suatu kelompok masyarakat, ataupun dari kondisi sosial keluarga dan latar belakang pendidikan. Secara singkat, kondisi anak marginal dikelompokkan dalam tiga aspek, meliputi: kondisi geografis, kondisi ekonomis, dan kondisi sosial.

\section{Kondisi Geografis}

Geografis tempat tinggal (dominasi) yang menetap dengan medan daerah terpencil/sulit merupakan keadaan yang mengharuskan penduduk setempat menghadapi berbagai masalah dan kendala hidup dalam berbagai kebutuhan hidup dan informasi lainnya. Hal ini dirasakan oleh masyarakat minoritas suku-suku bangsa di Provinsi Riau seperti Suku Akit, Bonai, Sakai, Talang Mamak, Duano atau Suku Laut lainnya serta pinggiran pantai, sungai dan mereka yang selama ini hidup di tengah hutan belantara.

Karakteristik anak marginal dari aspek geografis, meliputi: a) Anak-anak yang tinggal di pemukiman yang sangat jauh; dibatasi oleh laut, sungai, dataran tinggi, hutan, b) Orang tua yang enggan pindah lokasi menghindari bencana banjir dan gangguan alam lainnya. Sikap mereka tetap memilih tinggal di sana, berdampak kepada kehidupan anak, c) Anak-anak yang sulit mendapatkan akses dan teknologi informasi tentang pembaharuan

Kondisi marginal geografis di daerah yang berada di pinggir laut (selat malaka), bahkan sebagian daerah aliran sungai menyebabkan akses pendidikan secara fisik, menjadi langka sehingga anak-anak tetap mewarisi pola kehidupan orang tua secara turun temurun. 


\section{Kondisi Ekonomi}

Kondisi ekonomi yang dimaksudkan disini anatara lain dilihat dari tingakat pendapatan orang tua menurut UMP (Upah Minimum Provinsi), kondisi fisik tempat tinggal, serta kemampuan untuk menyediakan fasilitas pendidikan anak. Bagi anak-anak yang berada dalam kelompok ini disebut marginal ekonomi yang biasanya sangat rentan terhadap putus sekolah atau sama sekali belum pernah sekolah.

Karakteristik anak marginal dari aspek ekonomi, meliputi: a) Anak-anak dari keluarga miskin mayoritas diperlakukan sebagai mitra kerja untuk membantu ekonomi keluarga, b)Anak-anak pada usia sekolah (SD-SMP) dari keluarga miskin memilki peluang sempat untuk menikmati layanan pendidikan di sekolah, c) Anak-anak yang mengalami putus sekolah disebabkan tingginya tekanan ekonomi menyebabkan tidak sanggup mimikul biaya pendidikan, seperti biaya komite, harus berpakaian seragam, membeli buku pelajaran sekolah, biaya praktek, biaya kegiatan ekstrakurikuler lainnya.

Disamping hal diatas, kondisi masyarakat yang dikategorikan marginal karena masih menempati kehidupan pinggiran kota seperti Kota Pekanbaru yang selalu melakoni pola kehidupan ekonomi miskin atau tidak mampu, makan seadanya, hidup dalam rumah dan lingkungan yang kumuh dengan pola kehidupan mengemis. Dipahami akan mengalami kesulitan dalam pendidikan sebagai kasus kecil marginalisasi perkotaan.

\section{Kondisi Sosial}

Dalam kondisi sosial, biasanya anak-anak yang terbelenggu oleh lingkungan keluarga yang tidak harmonis dan atau lingkungan tempat tinggal yang tidak kondusif akan mempengaruhi kecacatan hari esok yang cemerlang.

Beberapa karakteristik anak marginal yang terhimpit oleh persoalan sosial sebagai berikut: a) Tidak pernah duduk di bangku sekolah oleh karena tradisi orang tua yang enggan menyekolahkan anak. Kelompok ini didominasi oleh sebagian dari komunitas suku terasing, b) Putus sekolah disebabkan retaknya harmonisasi keluarga, c)Tekanan perasaan dari temanteman sekelas disebabkan PR-PR sekolah berkaitan dengan biaya (cost) tidak dapat diselesaikan dengan tuntas menyebabkan untuk tidak masuk sekolah, d) Trauma akibat bencana alam, e) Selalu merasa rendah diri dan menyendiri dari kelompoknya sebagai konsekuensi potensi diri 
dan sikap disiplin kaku dari pihak sekolah, f) Selalu menolak perintah, mudah tersinggung dan merajuk, g) Berperilaku menyimpang.

Salah satu contoh anak marginal, adalah anak jalanan. Anak jalanan sudah merupakan kata yang biasa di dengar masyarakat. Manakala menyebut anak jalanan, perhatian orang akan tertuju pada sosok-sosok kumuh, dekil, liar, nakal dan selalu hadir di perempatan jalan, tumpukan sampah, pusat-pusat hiburan, keramaian atau terminal-terminal. Sosok anak jalanan, hingga kini merupakan manusia yang menempati kedudukan sangat hina di mata masyarakat umum. Penampilannya yang jorok, ekonomi keluarganya yang miskin, lingkungan pemukimannya di daerah-daerah kumuh atau bahkan sama sekali tidak mempunyai tempat tinggal tetap, perangainya yang liar dan sering melakukan kejahatan dan kekhasan lain anak jalanan, menyebabkan pandangan masyarakat terhadapnya sangat rendah. Ironisnya lagi, masyarakat bahkan tidak menganggap mereka sebagai manusia lazimnya. Sebab dalam anggapan mereka, anak jalanan adalah sampah yang tidak lagi mempunyai masa depan, tidak bisa diharapkan sebagai generasi penerus pembangunan dan tidak mempunyai manfaat bagi masyarakat. Jadi, anak jalanan adalah anak yang sebagian besar waktunya berada di jalanan, masih berusia 5-18 tahun dan melakukan kegiatan di jalanan, pasar, terminal dan tempattempat umum lainnya.

Menurut Yayasan Kesejahteraan Anak Indonesia, anak jalanan dibedakan menjadi empat kelompok, yaitu: pertama, anak-anak yang tidak berhubungan lagi dengan orang tuanya (children of the street). Mereka tinggal 24 jam di jalanan dan menggunakan semua fasilitas jalanan sebagai ruang hidupnya. Hubungan dengan keluarga sudah terputus. Kelompok anak ini disebabkan oleh faktor sosial psikologis keluarga, mereka mengalami kekerasan, penolakan, penyiksaan dan perceraian orang tua. Umumnya mereka tidak mau kembali kerumah, kehidupan jalanan dan solidaritas sesama temannya telah menjadi ikatan mereka. Kedua, anakanak yang berhubungan tidak teratur dengan orang tua. Mereka adalah anak-anak yang bekerja di jalanan (children on the street). Mereka sering kali diidentikkan sebagai pekerja migrant kota, yang pulang tidak teratur kepada orang tuanya di kampung. Pada umumnya mereka bekerja dari pagi sampai sore hari seperti menyemir sepatu, pengasong, pengamen, tukang ojek, penyapu mobil dan kuli panggul. Tempat tinggal mereka di lingkungan kumuh bersama dengan saudara atau teman-teman senasibnya. Ketiga, anak-anak yang berhubungan teratur dengan 
orang tuanya. Mereka tinggal dengan orang tuanya, mereka berada di jalanan sebelum atau sesudah sekolah. Motivasi mereka kejalan karena terbawa teman, belajar mandiri, membantu orang tua dan disuruh orang tua. Aktivitas usaha mereka yang paling menyolok adalah berjualan koran. Keempat, anak-anak jalanan yang berusia di atas 16 tahun. Mereka berada di jalanan untuk mencari kerja, atau masih labil suatu pekerjaan. Umumnya mereka telah lulus SD bahkan ada yang SLTP. Mereka biasanya kaum urban yang mengikuti orang dewasa (orang tua ataupun saudaranya) kekota. Pekerjaan mereka biasanya mencuci bus menyemir sepatu, membawa barang belanjaan (kuli panggul), pengasong, pengamen, pengemis dan pemulung.

Selanjutnya, secara garis besar anak jalanan dibagi kedalam tiga kelompok, yaitu: Pertama, children on the street, yakni anak-anak yang mempunyai kegiatan ekonomi sebagai pekerja anak di jalan, namun masih mempunyai hubungan yang kuat dengan orang tua mereka. Sebagian penghasilan mereka di jalan diberikan kepada orang tuanya. Anak jalanan pada kelompok ini membantu memperkuat penyangga ekonomi keluarganya karena beban atau tekanan kemiskinan.

Kedua, children of the street, yakni anak-anak yang berpartisipasi penuh di jalanan, baik secara sosial maupun ekonomi. Beberapa anak masih mempunyai hubungan dengan orang tuanya, tetapi frekuensi pertemuan mereka tidak menentu. Biasanya anak turun kejalanan disebabkan oleh kekerasan yang dilakukan oleh keluarga. Berbagai penelitian menunjukkan bahwa anak-anak yang pada kategori ini sangat rawan terhadap perilaku menyimpang, baik secara sosial, emosional, fisik maupun seksual.

Ketiga, children from families on the street, yakni anak-anak yang berasal dari keluarga yang hidup di jalanan. Walaupun anak-anak ini mempunyai hubungan kekeluargaan yang cukup kuat, tetapi hidup mereka berpindah-pindah dari suatu tempat ke tempat lain dengan segala resikonya.

\section{Pendidikan Anak Marginal}

Masyarakat kompetitif abad XXI merupakan produk dari sistem pembangunan pendidikan nasional yang mantap dan tangguh. Pendidikan nasional merupakan bagian dari pembangunan nasional, melalui Undang-Undang No. 20 Tahun 2003 dikatakan bahwa tujuan

pendidikan adalah: "untuk berkembangnya potensi peserta didik agar menjadi manusia yang 
beriman dan bertakwa kepada Tuhan Yang Maha Esa, berakhlak mulia, sehat berilmu, cakap, kreatif, mandiri, dan menjadi warga Negara yang demokratis serta bertanggung jawab.”

Selanjutnya dinyatakan bahwa Negara menjamin setiap warga Negara Indonesia mempunyai hak yang sama untuk memperoleh pendidikan yang bermutu, baik bagi warganegara yang memiliki kelainan fisik, emosional, mental, intelektual, dan/atau sosial, maupun warganegara di daerah terpencil atau terbelakang serta masyarakat adat yang terpencil, berhak memperoleh pendidikan khusus. Dengan demikian, anak-anak yang termajinalkan berhak mendapat pendidikan.

Oleh karena itu, pendidikan nasional telah memiliki dasar yang kuat, untuk menjaga hak semua warganegara untuk mendapatkan pendidikan. Namun demikian pendidikan nasional sebagai suatu sistem bukanlah merupakan sesuatu yang paten dan baku, namun merupakan suatu proses yang terus menerus mencari dan menyempurnakan bentuknya.

Masalah pendidikan nasional semakin kompleks sesuai dengan meningkatnya kesadaran masyarakat serta kemampuan sumber daya manusianya. Dari berbagai jenis masalah pendidikan, HAR Tilaar menulis empat permasalahan pendidikan, yaitu: 1) Peranan pendidikan dalam pembangunan nasional memasuki abad XXI dalam masyarakat yang serba terbuka, yang terpenting harus ditonjolkan antara lain mengenai reformasi pendidikan. 2) Pentingnya manajemen pendidikan agar dalam pembangunan sistem pendidikan nasional yang kuat dinamis menuju kepada kualitas output yang tinggi. 3) Kemajuan teknologi informasi yang mempengaruhi proses pendidikan dalam masyarakat ilmu. 4) Otonomi Daerah yang menuntut pembangunan pendidikan nasional yang memenuhi kebutuhan pembangunan daerah sebagai dasar pembangunan nasional dalam kerja sama regional.

Dengan demikian, dunia pendidikan haruslah berkembang sesuai dengan berkembangnya zaman yang saat ini melaju dengan pesat. Pendidikan haruslah didasarkan pada kebutuhan-kebutuhan dari seluruh potensi masyarakat Indonesia.

Dalam Keputusan Presiden No.36 tahun 1990 tentang hak-hak anak, dinyatakan seperti juga halnya orang dewasa memiliki hak dasar sebagai manusia. Akan tetapi karena kebutuhan-kebutuhan dan kerawanannya maka hak-hak anak perlu diperlakukan dan diperhatikan secara khusus. Dalam Keputusan ini Konvensi Hak Anak menyatakan bahwa setiap anak memiliki hak-hak sebagai berikut, yaitu: 
Pertama, hak untuk hidup. Setiap anak di dunia ini berhak untuk mendapatkan akses atau pelayanan kesehatan dan menikmati standard hidup yang layak, termasuk makanan yang cukup, air bersih dan tempat tinggal. Anak juga berhak memperoleh nama dan kewarganegaraan.

Kedua, hak untuk tumbuh dan berkembang. Setiap anak berhak memperoleh kesempatan untuk mengembangkan potensinya semaksimal mungkin. Anak berhak memperoleh pendidikan baik formal maupun informal secara memadai. Konkritnya anak berhak diberi kesempatan untuk bermain, berkreasi, dan beristirahat.

Ketiga, hak untuk memperoleh perlindungan. Artinya setiap anak berhak untuk dilindungi dari eksploitasi ekonomi dan seksual, kekerasan fisik atau mental, penangkapan atau penahanan yang sewenang-wenang dari segala bentuk diskriminasi. Ini juga berlaku bagi anak yang tidak lagi mempunyai orang tua dan anak-anak yang berada di kampung pengungsian. Mereka berhak mendapatkan perlindungan.

Keempat, hak untuk berpartisipasi. Artinya setiap anak diberi kesempatan menyuarakan pandangan dan ide-idenya, terutama berbagai persoalan yang berkaitan dengan anak. Dalam UU RI No.4 tentang Kesejahteraan Anak, menyatakan bahwa setiap anak berhak atas kesejahteraan, perawatan, asuhan dan bimbingan untuk tumbuh dan berkembang dengan wajar. Anak berhak atas pelayanan untuk mengembangkan kemampuan dan kehidupan sosialnya sesuai dengan kebudayaan dan kepribadian bangsa, untuk menjadi warga yang baik dan berguna. Anak juga berhak atas pemeliharaan dan perlindungan, baik semasa dalam kandungan maupun sesudah dilahirkan. Anak juga berhak atas perlindungan terhadap lingkungan hidup yang membahayakan atau menghambat pertumbuhan dan perkembangannya dengan wajar. Jadi, pada dasarnya hak-hak pokok anak adalah hak untuk hidup yang layak, hak atas kesejahteraan, perawatan, asuhan dan bimbingan untuk tumbuh dan berkembang dengan wajar, hak untuk dilindungi, hak atas pelayanan untuk mengembangkan kemampuan dan kehidupan sosialnya sesuai dengan kebudayaan dan kepribadian bangsa untuk menjadi warga yang baik dan berguna, hak untuk berperan serta, dan hak untuk memperoleh pendidikan.

\section{Pendidikan Kaum Marginal}


Manakala mengacu pada data-data resmi pemerintah, jumlah kaum miskin di Indonesia mencapai sekitar 30,02 juta jiwa atau 12,49\% dari total penduduk Indonesia yang mencapai 237,5 juta jiwa. Pertanyaan yang kemudian mendesak dikedepankan: Bagaimana proses pendidikan bagi kaum miskin itu berlangsung? Adakah akses yang memadai bagi anak-anak dari kalangan miskin untuk dapat mengenyam pendidikan? Ataukah keterpurukan mereka dalam bidang sosial dan ekonomi berbanding lurus dengan buruknya kondisi pendidikan? Apa yang semestinya dilakukan pemerintah demi memperbaiki taraf hidup kaum miskin melalui pendidikan?

Di wilayah-wilayah perkotaan, kaum miskin lebih tepat difrasakan sebagai "kaum marginal”. Dengan menyebutnya sebagai kaum marginal, maka ada dimensi sosiologis tertentu yang coba dimengerti dari peri kehidupan kaum miskin perkotaan. Beda dengan kaum miskin di perdesaan, kaum miskin perkotaan menatap dinamika dan gebyar modernisasi penuh warna. Kaum miskin perkotaan turut serta menjadi saksi mata terhadap derap perkembangan sosialekonomi dalam konteks modernisasi. Dengan menyebutnya sebagai kaum marginal, maka timbul pengakuan bahwa merekalah memang saksi mata modernisasi perkotaan, tapi tragisnya tak turut serta menikmati manfaat modernisasi.

Seperti halnya warga perkotaan pada umumnya, kaum marginal mutlak dan terkondisikan untuk terlibat dalam upaya-upaya pertahanan diri. Tetapi mekanisme pertahanan diri itu terbentang dalam berbagai ragam aktivitas ekonomi bawah tanah yang tak diperhitungkan oleh rezim kekuasaan. Jalan raya atau jalanan umum yang ramai merupakan domain kaum marginal untuk mengais naskah demi mempertahankan eksistensinya. Secara kategoris, mereka bekerja sebagai pengemis, pemulung sampah, pedagang asongan, pengamen, pemilik warung kecil, kuli bangunan dan pekerja seks komersial. Berapa jumlah riil populasi kaum marginal itu, hingga kini tak ada data pasti yang valid.

Manakala ditilik secara saksama, ada pembiaran terhadap nasib dan penderitaan kaum marginal itu. Hampir pada berbagai pemerintahan kota di segenap pelosok Nusantara, tak ada prakarsa-prakarsa yang bersifat manusiawi untuk memberikan alternatif pekerjaaan kepada kaum marginal. Artinya, rezim-rezim kekuasaan pada berbagai tingkatan abai terhadap nasib kaum marginal. Langsung maupun tak langsung, realitas ini berpengaruh terhadap proses 
pendidikan anak-anak dari kalangan kaum marginal. Sebagaimana kemudian dapat disimak secara kasat mata, anak-anak kaum marginal tak mendapatkan pendidikan secara layak.

Di kota besar semacam Jakarta, anak-anak kaum marginal bisa dengan sangat mudah terdeteksikan di bantaran rel kereta api, bantaran sungai dan kolong jembatan. Hidup dalam lingkungan kumuh, anak-anak ini merupakan potret dari generasi yang hilang (the lost generation), lantaran terabaikan hak-haknya untuk mengenyam pendidikan secara layak. Sekali pun Undang-Undang Dasar 1945 secara normatif menjamin hak hidup dan tumpah darah mereka sebagai warga negara, ternyata mereka diabaikan keberadaannya oleh rezim kekuasaan.

Terlebih lagi dalam situasi serba pelik tatkala jejaring kekuasaan diwarnai oleh regenerasi koruptor secara sistematis, pendidikan kaum marginal berada dalam kecenderungan besar untuk diabaikan secara sangat telak. Kecamuk korupsi dalam jejaring kekuasaan hanya mempertegas kehadiran aparat dan birokrat yang sama sekali tak merakyat, bahkan memusuhi kaum marginal.

\section{Pembinaan Anak Marginal}

Dalam mengatasi masalah yang dihadapi anak-anak tersebut, merupakan tugas sebagaimana yang diembangkan oleh pemerintah tentang pembinaan dan kesejahteraan anak dalam menjamin pertumbuhan dan perkembangannya dengan wajar baik jasmani, rohani maupun sosialnya.

Pembinaan yang harus dilakukan bervariasi dimana melalui proses pendidikan yang berkualitas dengan segala aspek. Pendidikan merupakan tanggung jawab bersama antara sekolah (Badan atau organisasi yang menyelenggarakan pendidikan secara formal), keluarga dan masyarakat. Ketiga lembaga pendidikan tersebut, Ki Hajar Dewantara menganggap lembaga tersebut sebagai Tri Pusat Pendidikan, yaitu Lembaga Pendidikan Keluarga (informal), Lembaga Pendidikan Sekolah (Formal), dan Lembaga pendidikan di Masyarakat (Non Formal).

\section{Lembaga Pendidikan Keluarga}

Lingkungan keluarga merupakan lingkungan pendidikan yang pertama, karena di dalam lingkungan keluarga inilah anak-anak pertama mendapatkan didikan dan bimbingan. Tugas utama keluarga bagi pendidikan, adalah sebagai peletak dasar pendidikan akhlak dan 
merupakan pandangan hidup keagamaan. Pelajaran yang paling berharga untuk anak adalah perangai ayah dan ibu sehari-hari, baik yang ditujukan kepada anak maupun yang lainnya.

Lembaga pendidikan keluarga memberikan pengalaman pertama bagi seorang anak dalam melangsungkan hidupnya sampai menjadi dewasa. Ini berarti peran orang tua sangat penting dalam membentuk watak dan karakter setiap anak maka tanggung jawab pendidikannya ada pada orang tuanya. Suasana pendidikan keluarga sangat penting diperhatikan, sebab dari sinilah keseimbangan jiwa didalam perkembangan individu selanjutnya di tentukan. Kewajiban orang tua tidak hanya memelihara eksistensi anak untuk dijadikan seorang pribadi, tetapi juga memberikan pendidikan sebagai individu yang tumbuh dan berkembang.

Di dalam keluarga, penanaman moral anak sangat diperlukan, yang biasanya tercermin dari sikap dan perilaku orang tua sebagai teladan yang dapat dicontoh anak. Dalam hubungan ini Ki Hajar Dewantara mengatakan: rasa cinta, rasa bersatu dan lain-lain. perasaan dan keadaan jiwa yang pada umumnya sangat berfaedah untuk kelangsungan pendidikan, teristimewa pendidikan budi pekerti, terdapatlah di dalam hidup keluarga dalam sifat yang kuat dan murni sehingga tak ada pusat pendidikan yang menyamainya.

Memang biasanya tingkah laku, cara berbuat dan berbicara, akan ditiru oleh anak. Dengan teladan ini, melahirkan gejala isentifikasi politik yakni penyamaan diri dengan orang yang ditiru. Segala nilai yang dikenal anak karena melekat pada orang-orang yang disenangi dan dikagumi, dan dengan melaui salah atau proses yang di tempuh anak melalui nilai.

Pendidikan keluarga merupakan basis yang sangat penting dalam peletakan dasar-dasar pendidikan social anak. Dalam keluarga anak-anak harus membantu (menolong) anggota keluarga yang lain, bersama-sama menjaga dan sebagainya. Kesemuanya memberikan pendidikan kepada anak, terutama memupuk perkembangan benih-benih kesadaran sosial pada anak.

Lembaga pendidikan keluarga sangat menentukan dalam menanam dasar-dasar internalisasi dan transformasi nilai-nilai keagamaan. Anak-anak seharusnya dibiasakan ke Masjid bersama-sama untuk menjalankan ibadah, mendengarkan khotbah, atau ceramahceramah keagamaan. Kenyataan membuktikan bahwa anak-anak yang terbiasa semasa kecilnya 
tidak tahu menahu dengan hal-hal yang berhubungan dengan hidup keagamaan, ketika ia dewasa nantinya tidak mempunyai keprihatinan terhadap kehidupan keagamaan.

\section{Lembaga Pendidikan Sekolah (Formal)}

Sekolah merupakan bagian dari pendidikan keluarga yang sekaligus juga lanjutan dari pendidikan keluarga. Yang disebut pendidikan sekolah adalah pendidikan yang diperoleh oleh seseorang dari sekolah secara teratur dan sistematis, bertingkat dan mengikuti syarat-syarat. yang jelas dan ketat mulai dari TK sampai dengan Perguruan Tinggi.

Ada beberapa karakteristik proses pendidikan yang dilangsungkan di sekolah: a) Diselenggarakan secara khusus, dibagi atas jenjang yang memiliki hubungan hirarkis, b) Usia anak didik disuatu jenjang pendidikan relative homogeny, c) Materi atau isi pendidikan lebih banyak bersifat akademis dan umum, dan d) Adanya penekanan tentang kualitas pendidikan sebagai jawaban atas kebutuhan dimana yang bersangkutan akan datang.

Sebagai lembaga pendidikan formal, sekolah yang lahir dan berkembang secara efektif dan efisien dari dan oleh serta masyarakat, merupakan perangkat yang berkewajiban memberikan pelayanan kepada masyarakat dalam mendidik warga Negara. Sekolah dikelola secara formal, hirarkis dan kronologis yang berhaluan pada falsafah dan tujuan pendidikan nasional.

\section{Lembaga pendidikan di Masyarakat (Non Formal)}

Dalam konteks pendidikan, masyarakat merupakan lingkungan ketiga setelah keluarga dan sekolah. Pendidikan yang dialami dalam masyarakat, telah dimulai ketika anak-anak untuk sementara waktu telah lepas dari asuhan keluarga dan berada dalam lingkungan sekolah. Pada hakekatnya pendidikan jalur sekolah terbagi dua, yakni pendidikan informal keluarga, pendidikan nonformal (masyarakat) pendidikan ini biasa disebut Lembaga Swadaya Masyarakt (LSM).

Pendekatan Lembaga Swadaya Masyarakat (LSM) berkembang diberbagai negara, suatu wahana yang dipersiapkan untuk memperantarai anak marginal dengan pihak yang akan membantu mereka. tekanan Lembaga Swadaya Masyarakat (LSM) yang lebih penting adalah mempertahankan kemampuan anak dimana penggunaannya berdasarkan aspirasi dan potensi yang dimiliki oleh anak. 
Lembaga Swadaya Masyarakat (LSM) merupakan proses informasi yang memberikan suasana rasionalisasi anak marginal terhadap sistem nilai dan norma yang berlaku di masyarakat.

LSM yang menangani pembinaan anak marginal adalah tersosialisasinya ide atau gagasan tentang perlunya minimalisasi atau antisipasi tindak kekerasan pada anak-anak dalam rumah tangga (keluarga) untuk sebuah proyeksitas terwujudnya generasi yang humanis dan anti kekerasan, tentang sosialisasi gagasan hak-hak anak akhirnya aturan hukum secara formal akan menjadi instrument untuk memajukan hal-hal di atas dalam dunia empiris. Sedangkan pembinaan khususnya adalah: a) Membangun kesadaran publik untuk ikut terlibat dalam minimalisasi dan antisipasi tindak kekerasan terhadap anak dirumah tangga (keluarga) juga, b) Sama-sama belajar konsep (formal dan informal) dalam meminimalisasi, mengantisipasi tindak kekerasan terhadap anak dalam rumah tangga, c) Mensosialisasikan kepada anak gagasan tentang upaya aturan hukum dalam meminimalisir, mengantisipasi kekerasan terhadap anak dalam keluarga dan dihormati hak anak, d) Memberikan ajaran agama secara teratur.

Melaksanakan hal-hal tersebut tentunya tetap memperhatikan hal yang lebih penting dengan kemampuan anak dimana penanganannya berdasarkan aspirasi dan potensi yang dimiliki anak.

\section{Keterampilan sebagai Salah Satu Faktor Pemberdayaan Anak Marginal}

Keterampilan merupakan kemampuan yang berasal dari pengetahuan, latihan, belajar, bakat untuk melakukan sesuatu yang baik. Keahlian khusus untuk melakukan sesuatu yang baik diperoleh dari belajar dan latihan, untuk itu anak jalanan sangat memerlukan bimbingan khusus agar memperoleh keterampilan dalam bekerja. Anak jalanan juga harus mendapat bimbingan dalam orientasi dan mobilitas, dimana dengan orientasi dan mobilitas serta pemahaman konsep-konsep anak jalanan mampu berjalan menuju dunia baru dengan percaya diri, antusias, dan mandiri. A. Mangunharjana mengemukakan bahwa program penanggulangan anak jalanan tidak terlepas dari proses pemberdayaan dan peningkatan skill dari anak jalanan tersebut. Pemberdayaan dan peningkatan skill adalah mengembangkan individu atau klien dari keadaan kurang mampu menjadi mampu, dan yang belum tahu menjadi tahu. Seperti yang dikemukakan oleh Sumarnonugroho, pemberdayaan untuk anak jalanan meliputi bantuan modal usaha, 
pendidikan, pelatihan dan keterampilan kerja sehingga anak jalanan akan menemukan pekerjaan lain. Karna itu suatu proses peningkatan keterampilan pada intinya ditujukan guna "individu memperoleh kemampuan untuk melakukan dan mengerjakan suatu kegiatan yang dapat membantu kelangsungan hidupnya”. Peningkatan keterampilan pada intinya membahas bagaimana individu, kelompok ataupun komunitas berusaha mengontrol kehidupan mereka sendiri dan dan membuat suatu usaha untuk membentuk masa depan sesuai dengan keinginan. Adapun upaya dalam peningkatan keterampilan anak jalanan yaitu adanya partisipasi dari berbagai pihak dalam menangani masalah anak jalanan yaitu, keluarga, tokoh agama, tokoh akademisi, aparat keamanan, aktivis LSM, masyarakat dan pemerintah. Menurut Soerdijan, menyebutkan bahwa program peningkatan keterampilan anak jalanan adalah: 1)Memberikan pendidikan bagi individu atau anak tentang keterampilan-keterampilan agar individu tersebut mempunyai keahlian guna memperoleh pekerjaan yang lebih layak, 2) Memberikan pelayanan/fasilitas yang memadai bagi anak jalanan guna kelancaran akan pengetahuan tentang keterampilan, dan 3) Memberikan bimbingan yang maksimal bagi anak jalanan dalam pendidikan dan keterampilan.

Keterampilan yang diperoleh anak dari rumah singgah akan dapat menjadi bekal hidup yang berharga kelak bila sudah keluar dari dunia anak jalanan. Pelayanan-pelayanan yang diberikan kepada anak akan sangat mendorong kelancaran proses tumbuh kembang yang pada gilirannya dapat ikut serta dalam pembangunan nasional dengan melaksanakan peran dan tugas sebagai generasi penerus bangsa.

\section{Pendidikan Anak Marginal dalam Perspektif Pendidikan Berbasis Masyarakat}

Pendidikan berbasis masyarakat adalah penyelenggaraan pendidikan berdasarkan kekhasan agama, social, budaya, aspirasi, dan potensi masyarakat sebagai perwujudan pendidikan dari, oleh, dan untuk masyarakat. (Sisdiknas, 2003)

Pelajaran, yang bisa ditarik dari Paolo Freire, filosof pendidikan terkemuka abad ke-20, untuk konteks pendidikan kita "kekinian”, paling tidak adalah betapa besarnya komitmennya terhadap kaum marginal. Lewat perspektif Freirean kita bisa bertanya: kepada siapa sesungguhnya sistem pendidikan kita saat ini berpihak? Apakah negara sudah sungguh-sungguh 
mengamalkan salah satu pasal UUD 1945 (hasil amandemen ke-4) yang berbunyi "anak-anak terlantar dipelihara oleh negara?"

Mengapa ada kesenjangan yang luar biasa tinggi dalam pendidikan kita, di satu sisi ada sekolah yang luar biasa mahal, dengan fasilitas yang lengkap, dan hanya orang kaya yang mampu menyekolahkan anaknya ke sekolah tersebut. Namun disisi yang lain ada sekolah yang dihuni kaum marginal saja? Bukankah dengan membiarkan kesenjangan itu terus berlangsung, sama dengan membenarkan tesisnya Samuel Bowles dan Herbert Gintis dalam "Schooling in Capilaist America (1976)," yang menyatakan bahwa sekolah hanya berfungsi sebagai alat untuk melayani kepentingan masyarakat dominan dalam rangka mempertahankan dan mereproduksi status quo?

Ada dua kelompok kaum marginal yang tereksklusi dan jarang mendapatkan perhatian serius oleh publik dalam hal pendidikan: Pertama, penyandang cacat. Kelompok ini termasuk mereka yang kurang beruntung mendapatkan pendidikan yang memadai. Mereka mengalami apa yang disebut segregasi pendidikan. Pendidikan mereka dibedakan dengan kaum "normal." Segregasi pendidikan ini telah berlangsung sekian lama dengan asumsi, mereka yang cacat dipandang tidak akan mampu bersaing dengan kaum "normal", karena tidak bisa bekerja maksimal. Jika asumsi ini benar, bukankah tugas sekolah untuk memaksimalkan mereka yang tidak mampu? Jika ada yang tidak mampu, mengapa solusinya tidak dengan pemberdayaan? Jika asumsi itu salah, bukankah itu sama saja menutup peluang mereka untuk mendapat pendidikan yang sama seperti yang diperoleh orang normal? Tidakkah ini berarti diskriminasi?

Dampak lain dari segregasi pendidikan adalah para penyandang cacat menjadi terasing dari lingkungan sosial, mereka tereksklusi dari sistem sosial orang-orang normal. Jadilah mereka sebagai warga kelas dua. Anak-anak normal juga tidak mendapat pendidikan pluralitas yang memadai. Bagaimana mereka bisa berempati dan bersimpati kepada penyandang cacat, jika mereka tidak pernah bergaul dengan kelompok ini karena hanya bergaul dengan sejenisnya di sekolah.

Kedua, anak-anak jalanan. Salah satu definisi menyebutkan bahwa anak jalanan merupakan "seseorang yang berumur dibawah 18 tahun yang menghabiskan sebagian atau seluruh waktunya di jalanan dengan melakukan kegiatan-kegiatan guna mendapatkan uang atau mempertahankan hidupnya." (Ishaq, 1998). Batasan umur dibawah 18 tahun digunakan dengan 
mengacu pada Konvensi Hak Anak. Sedangkan pengertian mengenai jalanan tidak sekedar menunjuk pada jalanan saja, tetapi juga pada tempat-tempat lain seperti mall, pasar alun-alun, terminal, taman kota, dan lain-lain.

Secara kuantitas kelompok ini kian banyak saja, terutama di kota-kota besar. Hasil Survei Sosial Ekonomi Nasional (SUSENAS) Badan Statistik Republik Indonesia tahun 1998 memperlihatkan bahwa anak jalanan secara nasional berjumlah sekitar 2,8 juta anak. Dua tahun kemudian, tahun 2000, angka tersebut mengalami kenaikan sekitar 5,4\%, sehingga jumlahnya menjadi 3,1 juta anak. Angka-angka tersebut menunjukkan bahwa kualitas hidup dan masa depan anak-anak sangat memprihatinkan. Padahal mereka adalah asset dan investasi Sumber Daya Manusia sekaligus tumpuan masa depan bangsa. Jika kondisi dan kualitas anak bangsa memprihatinkan, berarti masa depan bangsa dan negara juga kurang menggembirakan. Bahkan tidak tertutup kemungkinan, sebagian dari anak bangsa kita mengalami lost generation (generasi yang hilang).

Sebenarnya anak jalanan tidak berbeda dengan anak yang lainnya, mereka juga mempunyai potensi dan bakat. Pada masa anak-anak seperti itu otak yang memuat 100-200 milyar sel otak siap dikembangkan serta diaktualisasikan untuk mencapai tingkat perkembangan potensi tertinggi. Pada perkembangan otak manusia mencapai kapasitas $50 \%$ pada anak usia dini. Kita telah melupakan hak anak-anak untuk bermain, bersekolah, dan hidup sebagaimana lazimnya anak-anak lainnya. Mereka dipaksa orangtua untuk merasakan getirnya kehidupan. Mereka tumbuh dan berkembang dengan latar kehidupan jalanan dan akrab dengan kemiskinan, penganiayaan, dan hilangnya kasih saying sehingga memberatkan jiwa dan membuatnya berperilaku negatif.

Pasal 9 ayat (1) UU No 23 Tahun 2002 tentang perlindungan anak menyebutkan, "Setiap anak berhak memperoleh pendidikan dan pengajaran dalam rangka pengembangan pribadinya dan tingkat kecerdasannya sesuai dengan minat dan bakatnya." Pemenuhan pendidikan itu haruslah memperhatikan aspek perkembangan fisik dan mental mereka. Sebab, anak mempunyai dunianya sendiri dan berbeda dengan orang dewasa. Kita tak cukup memberinya makan dan minum saja atau melindunginya di sebuah rumah, karena anak membutuhkan kasih sayang. Kasih sayang adalah fundamen pendidikan. Tanpa kasih sayang, pendidikan ideal tidak mungkin di jalankan. 
Jika kita memakai perspektif Paulo Freire, kunci utama agar kedua kelompok itu bisa menjadi subjek yang otonom dan bisa mengkritisi realitas eksistensialnya adalah dengan cara mengembangkan kesadaran kritisnya dan mentransformasikan struktur sosial yang tidak adil. Kaum marginal harus diyakinkan bahwa mereka berhak dan mampu menentukan nasibnya sendiri, berhak mendapatkan keadilan, berhak melawan segala bentuk diskriminasi. melalui belajar. Karena itu perlu menggali sumber atau pendukung program baik melalui program sekolah maupun luar sekolah.

Oleh sebab, itu sudah saatnya kita mulai memperhatikan kelompok marginal tersebut secara sungguh-sungguh. Baik secara individu, organisasi kemasyarakatan, lembaga swadaya masyarakat (LSM), perusahaan-perusahaan maupun melalui yayasan-yayasan sosial milik masyarakat untuk bersikap empati dan mampu meyakinkan kepada mereka, bahwa program pendidikan tersebut benar-benar mendukung pengembangan diri mereka. Pendidikan kita sudah seharusnya berpihak kepada mereka, bukan mengabdi kepada kepentingan kekuasaan, industri, dan masyarakat dominan belaka. Inilah sesungguhnya yang kita kenal dengan pendidikan berbasis masyarakat, dimana pendidikan berasal dari masyarakat, oleh masayarakat, dan dikendalikan oleh masyarakat untuk masyarakat.

Pengendalian dapat dilihat dari aspek tujuan/sasaran, pembiayaan, kurikulum, materi belajar, standard dan ujian, persyaratan siswa/peserta, tempat, dan lain-lain. Sedangkan kadar pengendalian dapat dilihat dari aspek dukungan, keterlibatan, kemitraan, kepemilikan, dan pengambilan keputusan.

Ada empat peranan yang dapat dilakukan oleh berbagai lapisan masyarakat dalam pendidikan berbasis masyarakat ini: 1) Bagi tokoh masyarakat (agama, adat, dan pendidikan) dapat berperan sebagai pemrakarsa, mediator, motivator, tutor, pengelola dan bahkan sebagai penyandang dana serta penyedia fasilitas pendidikan; 2) Bagi organisasi kemasyarakatan berperan sebagai pemrakarsa, perencana, penyelenggara, organisator, pemberi motivasi, penyedia fasilitas, pengatur kegiatan, pengayom kegiatan, penyedia dana, Pembina kegiatan dan pemecah masalah; 3) Bagi lembaga swadaya masyarakat (LSM) dapat berperan sebagai pembangkit dan penyampai aspirasi masyarakat, pemberi motivasi, pendamping masyarakat, fasilitator, pengembang, penyedia dana, penyedia teknologi, penyedia informasi pasar, dan penyedia tenaga ahli dan pengelola program; 4) Bagi lembaga usaha/perusahaan dapat 
berperan sebagai penyelenggara pendidikan, penyedia fasilitas, penyedia tutor/instruktur, penyedia dana, penyedia fasilitas/informasi pasar, dan sebagai mitra usaha dalam mengelola produksi dari hasil usaha keterampilan yang telah dipelajari.

Pendidikan pada hakekatnya bertujuan membentuk karakter anak menjadi anak yang baik. Khusus untuk anak jalanan, pendidikan luar sekolah yang sesuai adalah dengan melakukan proses pembelajaran yang dilaksanakan dalam wadah rumah singgah.

Rumah singgah sebagai tempat pemusatan sementara yang bersifat non formal, dimana anak-anak bertemu untuk memperoleh informasi dan pembinaan awal sebelum dirujuk kedalam proses pembinaan lebih lanjut. Rumah singgah merupakan proses non formal yang memberikan suasana pusat resosialisasi anak jalanan terhadap sistem nilai dan norma di masyarakat. Tujuan dibentuknya rumah singgah adalah resosialisasi atau membentuk kembali sikap dan perilaku anak yang sesuai dengan nilai-nilai dan norma yang berlaku di masyarakat, memberikan pendidikan dini untuk pemenuhan kebutuhan anak, dan menyiapkan masa depannya agar menjadi masyarakat yang produktif.

Peran dan fungsi rumah singgah bagi program pemberdayaan anak jalanan sangat penting. Adapun fungsi dari rumah singgah antara lain: 1) sebagai tempat perlindungan dari berbagai bentuk kekerasan yang kerap menimpa anak jalanan dari kekerasan perilaku penyimpangan seksual ataupun berbagai bentuk kekerasan lainnya, 2) rehabilitasi, yaitu mengembalikan dan menanamkan fungsi sosial anak, 3) sebagai akses terhadap pelayanan, yaitu sebagai persinggahan sementara anak jalanan dan sekaligus akses berbagai pelayanan sosial seperti pendidikan, kesehatan, dan lain-lain. Lokasi rumah singgah harus berada di tengahtengah masyarakat agar memudahkan proses pendidikan dini, penanaman norma, dan resosialisasi bagi anak jalanan.

Dengan masuknya anak marginal ke bangku sekolah, maka akan mengurangi jumlah anak yang tidak sekolah dan yang putus sekolah. Hal ini pada akhirnya akan memperbaiki kondisi pendidikan di Indonesia, yang dinilai masih rendah dibanding dengan negara-negara lain. Sangat penting untuk memberi kesempatan anak marginal untuk mendapatkan pendidikan yang sama dengan anak-anak lainnya. Karena ini bukan hanya tugas pemerintah tetapi juga kewajiban semua masyarakat. 


\section{SIMPULAN}

Bila dikaitkan dengan kondisi masyarakat, marginal adalah kelompok manusia yang masih dikategorikan terpinggir dari kemajuan zaman. Marginal (terpinggir atau pinggiran) adalah kategorisasi daerah/kelompok komunitas dan kondisi hidup dalam pranata sosial yang dirabaikan dalam tatanan kehidupan masyarakat modern. Variasi kondisi anak marginal dapat dilihat dari aneka ragam dan bentuk status ekonomi, lokasi geografis tempat tinggal suatu kelompok masyarakat, ataupun dari kondisi sosial keluarga dan latar belakang pendidikan.

Hasil penelitian menyimpulkan bahwa : 1) Di wilayah-wilayah perkotaan, kaum miskin lebih tepat difrasakan sebagai "kaum marginal", 2) Hidup dalam lingkungan kumuh, anak-anak kaum marginal merupakan potret dari generasi yang hilang (the lost generation), lantaran terabaikan hak-haknya untuk mengenyam pendidikan secara layak.

Upaya yang dapat dilakukan untuk memperbaiki pendidikan anak marginal adalah memberikan pendidikan bagi individu atau anak tentang keterampilan-keterampilan agar individu tersebut mempunyai keahlian guna memperoleh pekerjaan yang lebih layak, dan memberikan pelayanan/fasilitas yang memadai bagi anak-anak marginal guna kelancaran akan pengetahuan tentang keterampilan, serta memberikan bimbingan yang maksimal bagi anakanak marginal dalam pendidikan dan keterampilan.

Sudah saatnya semua elemen masyarakat mulai memperhatikan kelompok marginal tersebut secara sungguh-sungguh. Baik secara individu, organisasi kemasyarakatan, Lembaga Swadaya Masyarakat (LSM), perusahaan-perusahaan maupun melalui yayasan-yayasan sosial milik masyarakat, upaya yang dapat dilakukan adalah dengan menyelenggarakan program pendidikan luar sekolah berupa kegiatan resosialisasi di Rumah Singgah. Pendidikan sudah seharusnya berpihak kepada mereka bukan mengabdi kepada kepentingan kekuasaan, industri, dan masyarakat dominan belaka

\section{DAFTAR PUSTAKA}

Freire, Paulo. (1984). Pendidikan, Pembebasan, Perubahan Sosial. Jakarta: PT. Sangkala Pulsar Ishaq, M. (1998). Pengembanga Modul Literasi Jalanan Untuk Peningkatan Kemampuan Hidup Bermasyarakat Anak-anak Jalanan. Makalah Lokakarya Modul Literasi Jalanan di BPKB. Bandung: Yayasan Bahtera-Unicef 
http://id.shvoong.com/social-sciences/anthropology/2134959-anak-anak-marginal-yangterlupakan/\#ixzz1nONVM1OD

http://edukasi.kompas.com - 8 Januari 2010

http://www.riauterkini.com - 12 Januari 2010

Kasmianto, dkk. (2007). Panduan dan Potret Pendidikan Anak Marginal. Upaya Mencerdaskan Anak Bangsa sampai ke Pelosak Negeri. Pekanbaru: Unri Press

Maksum, Ali dan LY. Ruhendi (2002). Paradigma Pendidikan Universal di Era Modern dan Post Modern. Yogyakarta: IRCISOD

Mujiburrahman, 2014. "Islam, Perempuan dan Pendidikan" Marwah Jurnal Perempuan, Anak dan Jender Vol 13 No.1 Juni Tahun 2014 Hal 25.

Reza Bastian, Aulia. (2002). Reformasi Pendidikan; Langkab-langkah Pembaharuan dan Pemberdayaan Pendidikan Dalam Rangka Desentralisasi Sistem Pendidikan Indonesia. Yogyakarta: Lappera Pustaka Utama

Suyanto. (2006). Dinamika Pendidikan Nasional - Dalam Percaturan Dunia Global. Jakarta: PSAP Muhammadiyah

Zubaida. (2005). Pendidikan Berbasis Masyarakat. Upaya Menawarkan Solusi Terhadap Berbagai Problem Sosial. Yogyakarta: Pustaka Pelajar. 